Annals of Warsaw University of Life Sciences - SGGW

Land Reclamation No 43 (2), 2011: 193-205

(Ann. Warsaw Univ. of Life Sci. - SGGW, Land Reclam. 43 (2), 2011)

\title{
Turbulent kinetic energy of water in a compound channel
}

\author{
ADAM PAWEŁ KOZIOŁ \\ Department of Hydraulic Engineering, Warsaw University of Life Sciences - SGGW
}

\begin{abstract}
Turbulent kinetic energy of water in a compound channel. The aim of the experimental research was the determination of water turbulent kinetic energy changes in a compound channel without and with rigid, emergent, vegetation existing on floodplains. Two tests for two various roughness of floodplains were realized. In the first test the surface of the main channel bed was smooth and made of concrete whereas the floodplains and sloping banks were covered by cement mortar composed with terrazzo. In the second test the covering of the floodplains was left as in the first test but additionally emergent vegetation (trees) growing on the floodplains were modeled by aluminium pipes. Instantaneous velocities were measured with use of a three-component acoustic Doppler velocity meter (ADV). The influence of trees, located on floodplains, on the distributions of turbulent kinetic energy in the main channel and on the floodplains were presented. The distributions of turbulent kinetic energy at different water depths were described by regression equations. Vertical distributions of turbulent kinetic energy on the floodplains and over the banks of the main channel were divided into three zones. Over the bottom of the main channel, four zones were determined, containing the middle zone of the flow field divided into two zones of different trends.
\end{abstract}

Key words: compound channel, turbulent kinetic energy, vegetation, floodplains.

\section{INTRODUCTION}

The research on the turbulent water flow structure in channels and rivers is realized worldwide nowadays. Without the recognition of turbulence structure in a compound channel, it is impossible to properly understand the processes happening during the flow of water. The scale of interest in those research problems is reflected by a very high number of relevant scientific papers. On the basis of those papers, it can be concluded, that the research on turbulence characteristics of water flow is realized both on small-scale and large scale models of single or compound channels and it is as well realized in rivers (Czernuszenko and Lebiecki 1980; Nezu and Rodi 1986; Knight and Shiono 1990; Nikora et al. 1994; Nikora and Smart 1997; Rowiński et al. 1998; Babaeyan-Koopaei et al. 2002; Rowiński et al. 2002; Yang et al. 2007; Mazurczyk 2007; Sanjou et al. 2010; Terrier et al. 2010).

Low vegetation (e.g. grass) and tall one (steams and trees) existing in the cross-sectional area of river channels, cause the increase of motion resistance, change velocity distributions and influence water depth. Additionally, water flow characteristics in the compound channel are considerably different from single channel characteristics. Because the shape of the cross section varies and the roughness of the main channel and floodplains is very often different, the flow structure of a compound channel is 
usually very complex. The research on flow conditions of channels with elastic and rigid vegetation is realized in a very broad range of vegetation density- from dense vegetation (Nepf 1999; Ben Meftah et al. 2006; Mazurczyk 2007a) to single plants in a cross-section (Ingo et al. 2007; Sanjou et al. 2010; Terrier et al. 2010) both for submerged and emergent vegetation.

Turbulent kinetic energy (TKE) is the mean kinetic energy per unit mass of fluid in relation with turbulent flow eddies. Physically, it is characterized by the measured, mean squared (RMS) velocity fluctuation. On the basis of three-dimensional turbulent velocity values - along 3 axes: $\{x, y, z\}$, the longitudinal turbulent intensity u', the transverse turbulent intensity v' and the vertical turbulent intensity w' were calculated, and then the turbulent kinetic energy (TKE) $k$, was calculated (Nezu and Nakagawa 1993) according to the following formula:

$$
k=0.5\left(u^{\prime 2}+v^{\prime 2}+w^{\prime 2}\right)
$$

The turbulent kinetic energy is produced by shear and wakes. In principle shear production converts mean kinetic energy to turbulence and at the same time wakes are created as an effect of work against form drag (Rowiński and Mazurczyk 2006). This is characteristic of turbulence in vegetated areas only (on floodplains) and has very important consequences. It makes the vertical distribution of longitudinal turbulent intensity and kinetic energy much more uniformly distributed (Rowiński et al. 2002), which is particularly evident in this case on floodplains.
According to Grinvald and Nikora (1988) the share of longitudinal turbulence intensity in kinetic energy is dominant and ranges from 55 to $80 \%$. In the analyzed channel, the share of longitudinal turbulence intensity in the kinetic energy was about $50 \%$. The lower percentage share of longitudinal turbulence intensity, in the analyzed case, results from a complex cross-sectional area and relatively small main channel roughness, which contributes to the process of water mixing between the main channel and the floodplains for the whole analyzed channel width (Mazurczyk 2007). This process significantly influences the increase of turbulence intensity in the transverse direction. This is why the determination of turbulence structure, especially in the case of channels with a complex cross-section, requires the measurements of velocities with proper probes at least in two directions - the longitudinal and the transverse one. Usually, the vertical turbulence intensity has the lowest share in the kinetic energy-not exceeding several percents. Grinvald and Nikora (1988), basing on their research results, proved, that the share of vertical turbulence intensity in the kinetic energy decreases downwards to the bottom. The measurements in the field proved their observations, however only for main channels.

Nezu and Nakagawa (1993) proposed the description of the distribution of vertical turbulent kinetic energy in the form of exponential regression equation, valid for the intermediate region of single channels for steady two-dimensional flow. Knight and Shiono (1990) found, that in a channel of a complex cross-section, there is the similarity of turbulent kinetic energy distribution, and the best 
fit to the exponential regression equation was obtained for the channel centerline. They found also that the data revealed the three dimensional nature of the flow in regions where strong lateral shear and secondary flow exit. In a straight compound channel with rigid and flexible emergent floodplain vegetation, Schnauder (2004) confirmed that secondary currents are the primary mechanism for momentum exchange, and the magnitude of the boundary turbulent kinetic energy between the vegetation and the main channel is a function of both the relative depth and the floodplain vegetation properties. The highest turbulent kinetic energy was measured for flexible vegetation arrangements compared to the rigid at the highest flow discharges. Schnauder (2004) showed that in fact the lower density flexible vegetation produces higher turbulent kinetic energy then the denser rigid setup and suggested that vegetation flexibility has stronger influence on turbulent kinetic energy field then the vegetation density.

On the model of the open, trapezoidal compound channel, the research on the structure of turbulent water flow was performed. One and three dimensional measurements of water velocities were used to determine basic turbulence parameters in the cross-section, and the structure of turbulence on vegetated and non-vegetated floodplains (Kozioł et al. 1998; Rowiński et al. 1998; Kozioł 2002; Rowiński et al. 2002; Czernuszenko et al. 2007; Kozioł 2008).

The aim of the research was the analysis of changes and the distribution of turbulent kinetic energy of water in a compound channel, influenced by trees located on floodplains. The determined changes of turbulent kinetic energy at selected vertical profiles: on floodplains, on the banks of the main channel and over the bottom of the main channel, were described with regression equations. The areas of changes in the trend of turbulent kinetic energy were also analyzed in the vertical profile of the main channel.

\section{EXPERIMENTAL ARRANGEMENTS AND METHODOLOGY}

The experiments considered herein were carried out in the Hydraulic Laboratory of the Department of Hydraulic Engineering, Faculty of Civil and Environmental Engineering at the Warsaw University of Sciences - SGGW. A straight open channel with symmetrically complex trapezoidal cross section, $16 \mathrm{~m}$ long and $2.10 \mathrm{~m}$ wide was used for the laboratory tests. The bed slope of the channel was $0.5 \%$ and the water surface was kept almost parallel to the bed during the experiments. A uniform and steady flow was achieved in every case. Water discharges were recorded with use of a measuring circular overfall - $540 \mathrm{~mm}$ in diameter. Water surface slope was measured by recording the pressure differences among piezometers located along the centerline of the channel bed at the distances 4 and $12 \mathrm{~m}$ from the channel entrance. The main channel width was equal to $30 \mathrm{~cm}$ and the floodplains' width was $60 \mathrm{~cm}$. The sloping banks were inclined at the angel 1:1.

Two tests for two various roughness of floodplains were realized (Fig. 1). In the first experiment, the surface of the main channel bed was smooth (Manning roughness coefficient $n=0.011 \mathrm{~m}^{-1 / 3} \mathrm{~s}$ ) and made of concrete whereas the flood- 
plains and sloping banks were covered by cement mortar composed with terrazzo with grains of 0.5 to $1 \mathrm{~cm}$ in diameter (Fig. 1a). Average Manning's roughness coefficient for the rough surfaces of overflow area channel equaled about $n=$ $=0.018 \mathrm{~m}^{-1 / 3} \mathrm{~s}$ for the left and $0.025 \mathrm{~m}^{-1 / 3} \mathrm{~s}$ for the right overflow area. The values of absolute roughness of the channel surface were determined from the Colebrook - White equation on the basis of the average velocity values of the flow measured in those parts of the channel. The obtained roughness amounted to $k_{s}=$ $=0.00005 \mathrm{~m}$ for the smooth surfaces, $k_{s}=0.0074 \mathrm{~m}$ for the rough surface of the left overflow area, and $k_{s}=0.0124 \mathrm{~m}$ for the rough surface of the right overflow area. In the second experiment, the covering of the floodplains was left as in the first experiment but additionally high vegetation (trees) growing on the floodplains were modeled by aluminum pipes of $0.8 \mathrm{~cm}$ diameter, placed with both longitudinal and lateral spacing's of $20 \mathrm{~cm}$ (Fig. 1b, Fig. 2). There were 8 pipes in each of 161 cross-sections. The "tree-tops" were above water level during the experiments and the pipes were not subject to any elastic strains caused by overflowing

a) Experiment 1

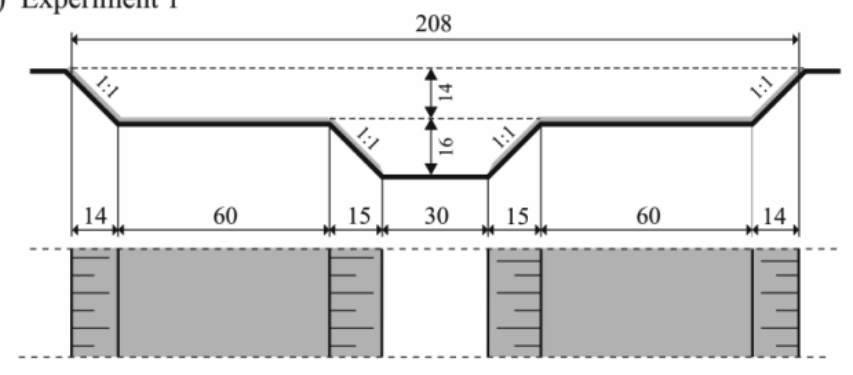

b) Experiment 2
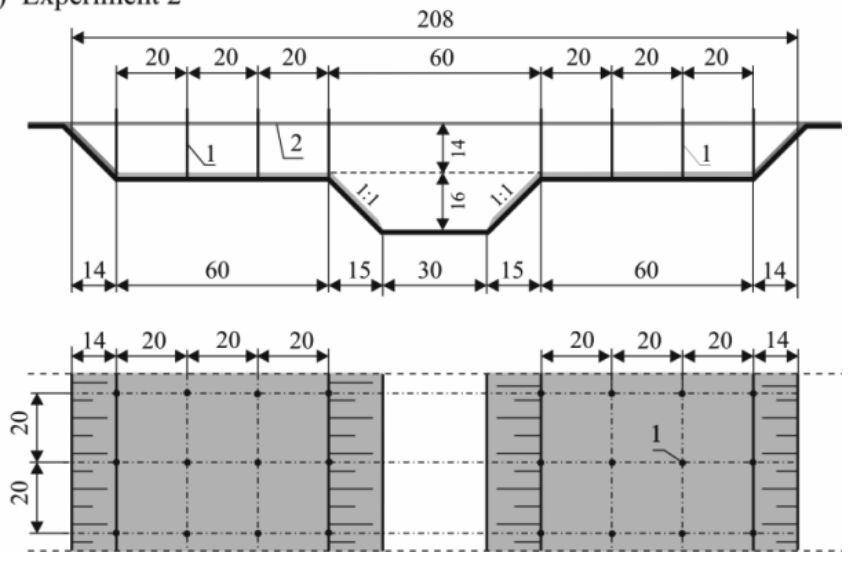

FIGURE 1. Scheme of a laboratory cross-section for five considered tests: a) experiment 1 in a channel with the smooth bed of the main channel and rough floodplains, b) experiment 2 in a channel with the smooth bed of the main channel and rough floodplains vegetated with trees, 1 - pipes imitating trees, 2 - wooden strips supporting the trees (dimensions in $\mathrm{cm}$ ) 


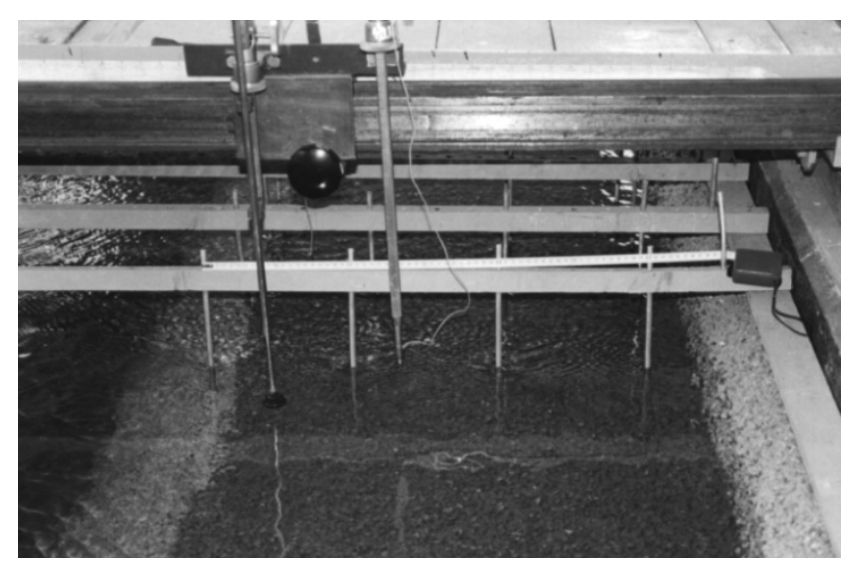

FIGURE 2. The view of the model of the channel for the experiment 2 with pipes imitating the trees

water. The hydraulic parameters of conducted researches were introduced in the Table 1.

TABLE 1. The Hydraulic parameters of conducted researches

\begin{tabular}{|l|c|c|}
\hline \multirow{2}{*}{ Parameter } & \multicolumn{2}{|c|}{ Experiment } \\
\cline { 2 - 3 } & 1 & 2 \\
\hline Discharge $Q[1 / \mathrm{s}]$ & 95.2 & 65.7 \\
\hline $\begin{array}{l}\text { Depth in the main channel } \\
H[\mathrm{~cm}]\end{array}$ & 28.3 & 28.0 \\
\hline Depth in the floodplain $h_{f}[\mathrm{~cm}]$ & 12.3 & 12.0 \\
\hline Relative depth $D r=h_{f} / H$ & 0.43 & 0.43 \\
\hline Vegetation on the floodplains & - & trees \\
\hline The sloping banks [-] & \multicolumn{2}{|c|}{$1: 1$} \\
\hline The bed slope $i[\%]$ & \multicolumn{2}{|c|}{0.5} \\
\hline
\end{tabular}

Water levels in the main channel and on the floodplains, all three components of point velocities, water temperature and water discharge were measured during the course of the experiment. The cross-section at the half of the channel length was selected for velocity measurements (Fig. 3). It consisted of 23 verticals - six on each floodplain and eleven in the main channel.

Instantaneous velocities were measured with use of a three-component acoustic Doppler velocity meter (ADV) manufactured by Sontek Inc. The acoustic sensor was mounted on a rigid stem attached to a specially designed trolley allowing for its detailed positioning. ADV works

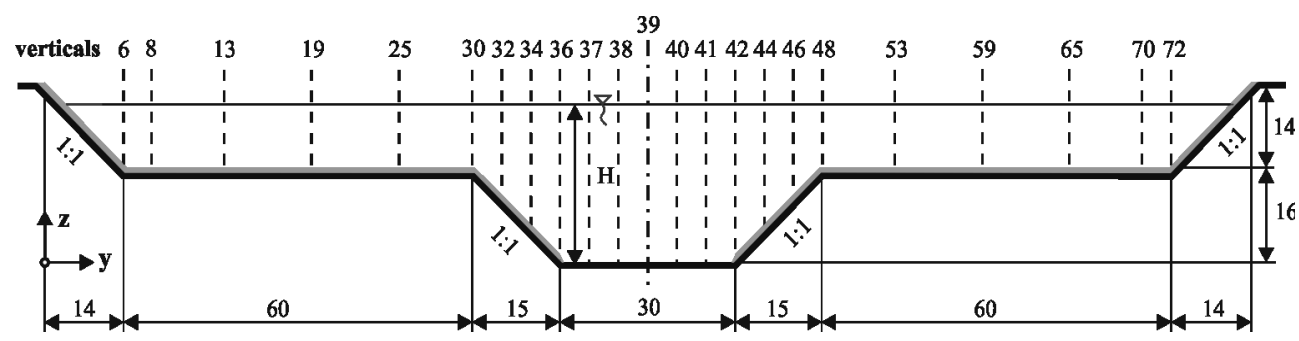

FIGURE 3. Scheme of the experimental cross-section with the arrangement of measuring verticals (dimensions in $\mathrm{cm}$ ) 
on pulse-to-pulse coherent Doppler techniques in relatively high temporal resolution. ADV proved to yield a good description of the turbulence characteristics when certain conditions related to the flow itself and the configuration of the instrument are satisfied. The measurements were conducted with maximum frequency $25 \mathrm{~Hz}$ in the velocity range of 0 to $1.0 \mathrm{~m} / \mathrm{s}$ with the accuracy of 0.25 $\mathrm{cm} / \mathrm{s}$. More detailed information's about the methodology are found in the paper Czernuszenko at al. (2007).

\section{RESULTS AND ANALYSIS}

\section{Turbulent kinetic energy in the compound channel for nonvegetated floodplains}

Figure 4 presents vertical turbulent kinetic energy distributions (TKE) in the main channel and on the floodplains, achieved in experiment 1 (smooth main channel bottom, rough surface of the main channel banks and floodplains) and in experiment 2 (additionally emergent vegetation - trees growing on the floodplains). Turbulent kinetic energy is calculated on the basis of the turbulence intensity, and that's why vertical distributions of TKE are almost identical to the distributions of the relative turbulence intensity in the longitudinal direction, in relation to the relative depth $\mathrm{z} / \mathrm{h}(z-$ distance from measurement point to the bed surface, $\mathrm{h}-$ depth in measuring vertical). In experiment 2 over the main channel, from the floodplain elevation $(0.56 z / h)$ downwards to the bottom, TKE values increase and the best fit is achieved by linear regression equation. Over the floodplain elevation, TKE values do not change with depth, until $0.9 \mathrm{z} / \mathrm{h}$ (Fig. 4).
In the zone near the water surface, the steadiness of turbulent kinetic energy is visible, which is caused by the process of significant mixing and the exchange of water between the main channel and floodplains. At depths higher than $0.9 \mathrm{z} / \mathrm{h}$, very close to the water surface, TKE values increase.

Figure 5 presents vertical distributions $k / U_{*}^{2}$ over the bottom and the linear regression equations, describing the energy distribution versus the water depth in the centerline of the main channel (vertical 39). Friction velocity $U_{*}$ was determined from measured Reynolds stress distribution (Tab 2; Nezu and Nakagawa 1993; Rowiński et al. 2005). In the channel of a compound cross-section, with rough floodplains and rough main channel banks, it is not possible to apply one equation for vertical turbulent energy $k / U_{*}^{2}$ distribution over a smooth main channel bottom, which is also proved by research of Knight and Shiono (1990). The work by Knight and Shiono (1990) focused on a channel with a smooth bottom surface and of a similar cross-section, and as they suggested, there was the similarity of energy $k / U_{*}^{2}$ description over the main channel bottom by exponential regression equation, which gave the best fit at the channel centerline for $z / h<0.6$. Nezu and Nakagawa (1993) proposed the following exponential regression equation for the description of turbulent kinetic energy distribution in single channels in the conditions of steady two-dimensional flow in the intermediate region $(0.1<z / h<0.6)$ :

$$
k / U_{*}^{2}=4.78 \exp (-2 z / h)
$$

In experiment 1 , that focuses on the main channel with a smooth bottom and 

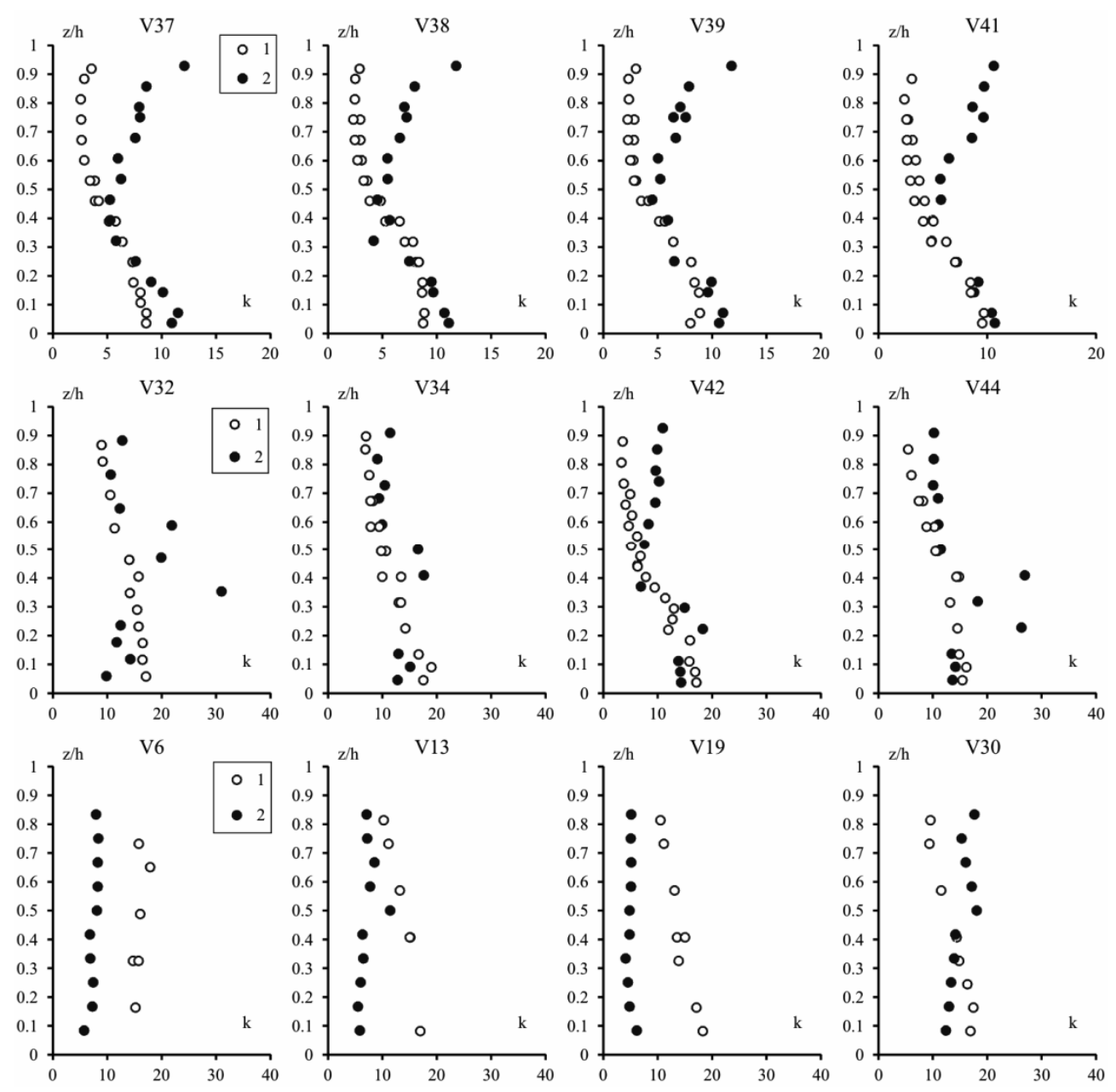

FIGURE 4. Vertical distributions of turbulent kinetic energy $k\left[\mathrm{~cm}^{2} / \mathrm{s}^{2}\right]$ in experiment 1 and 2

TABLE 2 . Friction velocity $U_{*}(\mathrm{~m} / \mathrm{s})$

\begin{tabular}{|c|c|c|c|c|c|c|c|c|c|c|c|c|c|c|}
\hline \multirow{2}{*}{ Exp. } & \multicolumn{10}{|c|}{ Verticals } \\
\cline { 2 - 14 } & 6 & 8 & 13 & 19 & 30 & 32 & 34 & 37 & 38 & 39 & 40 & 41 & 42 & 44 \\
\hline 1 & 0.014 & 0.022 & 0.021 & 0.023 & 0.022 & 0.016 & 0.019 & 0.014 & 0.015 & 0.016 & 0.015 & 0.015 & 0.018 & 0.018 \\
\hline 2 & 0.006 & 0.011 & 0.011 & 0.012 & 0.014 & 0.013 & 0.012 & 0.013 & 0.014 & 0.012 & 0.013 & 0.013 & 0.016 & 0.013 \\
\hline
\end{tabular}

rough banks, the distribution of turbulent a high variability of analyzed parameters kinetic energy $k / U_{*}^{2}$ cannot be described (Fig. 5). The highest energy values $k / U_{*}^{2}$ with one regression equation for the are achieved at the channel centerline whole smooth bottom width, because of (vertical V39), and their vertical distri- 


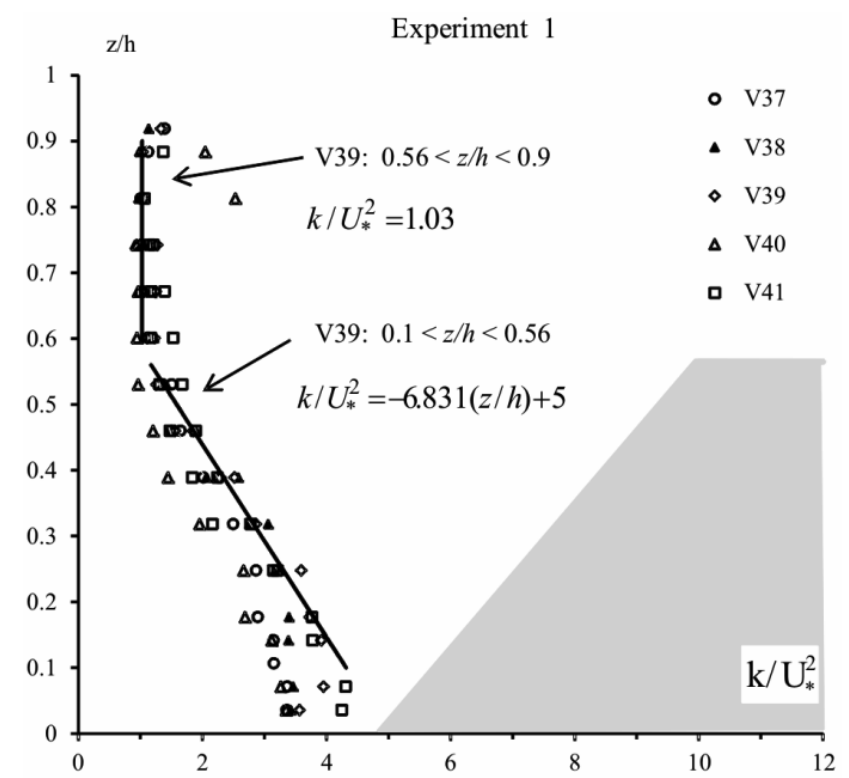

FIGURE 5. Vertical distributions of turbulent kinetic energy $k / U_{*}^{2}$ over the bed of the main channel in experiment 1
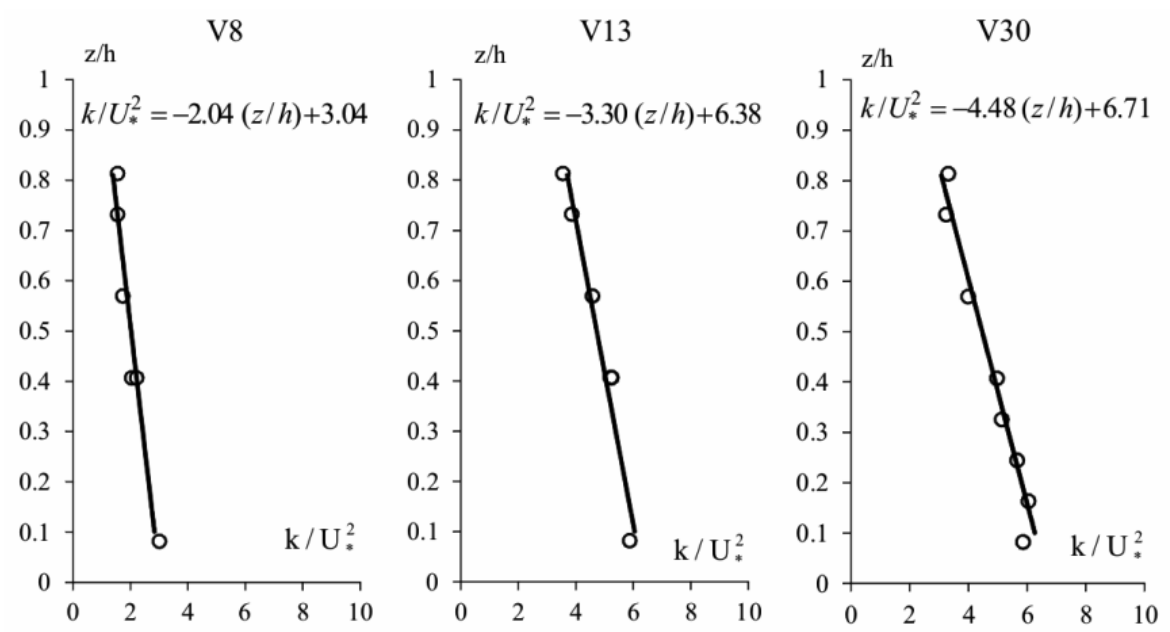

FIGURE 6. Vertical distributions of turbulent kinetic energy $k / U_{*}^{2}$ on the floodplains in experiment 1

bution was described with the following linear regression equation, in the region $0.1<z / h<0.56$,

$$
k / U_{*}^{2}=-6.831(z / h)+5
$$

However, over the floodplain elevation, the energy values $k / U_{*}^{2}$ are constant with depth in the region $0.56<z / h<0.9$, (3) and are equal to 1.03 . 
Over the banks of the main channel (vertical 32, 34, 42 and 44) and on the floodplains (verticals 6-30) TKE values increase downwards to the bottom (Fig. 4), where the best fit is achieved by linear regression equation, in the region $0.1<z / h<0.81$ (Fig. 6). Turbulent kinetic energy on floodplains is considerably higher than in the main channel.

\section{Turbulent kinetic energy in the compound channel with emergent vegetation (trees) on the floodplains}

Figure 4 presents vertical distributions of turbulent kinetic energy in the main channel and on the floodplains for experiment 1 and 2 with trees existing on the floodplains. In experiment 2 vertical distributions of kinetic energy were also described with regression equations, but only for the main channel. In experiment 2, TKE values almost do not change with depth over the banks of the main channel (verticals 32-34 and 42-44), while below the depth of $0.46 \mathrm{z} / \mathrm{h}$ higher fluctuations are observed (Fig. 4). TKE values are lower at the bottom, while in the zone near the water surface they are higher in the experiment with trees on the floodplains.

On the floodplains in experiment 2, at all verticals (Fig. 4, V6-19), TKE values do not change with depth and reach lower values than in the experiment without trees. This is characteristic of turbulence in vegetated areas only (emergent vegetation like shrubs and trees) and has very important consequences. It makes the vertical distribution of longitudinal turbulent intensity and kinetic energy much more uniformly distributed (Rowiński et al. 2002), which is particularly evident in this case on floodplains. According to Nepf and Vivoni (1999) in the flow of water influenced by rigid tall vegetation, as a result of resistance generated by tree-trunks and stems, the mean motion energy transforms into turbulent kinetic energy, which causes the considerable increase of its value. In the experiment 2, the trees caused the decrease of TKE value (Fig. 4). Similar results were achieved by Grinvald and Nikora (1988), proving the hypothesis, that the occurrence of wakes doesn't cause the increase of TKE. They concluded, that the introduction of vegetation, which visible effect is the break of eddies and the decrease of eddies length, influences the increase of energy dissipation, but not the production of turbulent kinetic energy. According to Rowiński et al. (2002), however, the presence of trees on floodplains causes the decrease of the length of macro-eddies and also decrease of the dissipation rate of turbulence.

Figure 7 presents vertical distributions of turbulent kinetic energy $k / U_{*}^{2}$ for experiment 2, over the bottom of the main channel, along with regression equations describing that distribution in the centerline of the main channel (vertical 39). The best fit was achieved for the following linear regression equations in the range $0.1<\mathrm{z} / \mathrm{h}<0.46$ in which the energy values $k / U_{*}^{2}$ increase downwards to the bottom,

$$
k / U_{*}^{2}=-11.438(z / h)+8.373
$$

and for water depths higher than $0.46 z / h$ the energy values $k / U_{*}^{2}$ increase upwards to the surface of water, according to the following equation, derived for the range $0.46<\mathrm{z} / \mathrm{h}<0.9$ : 


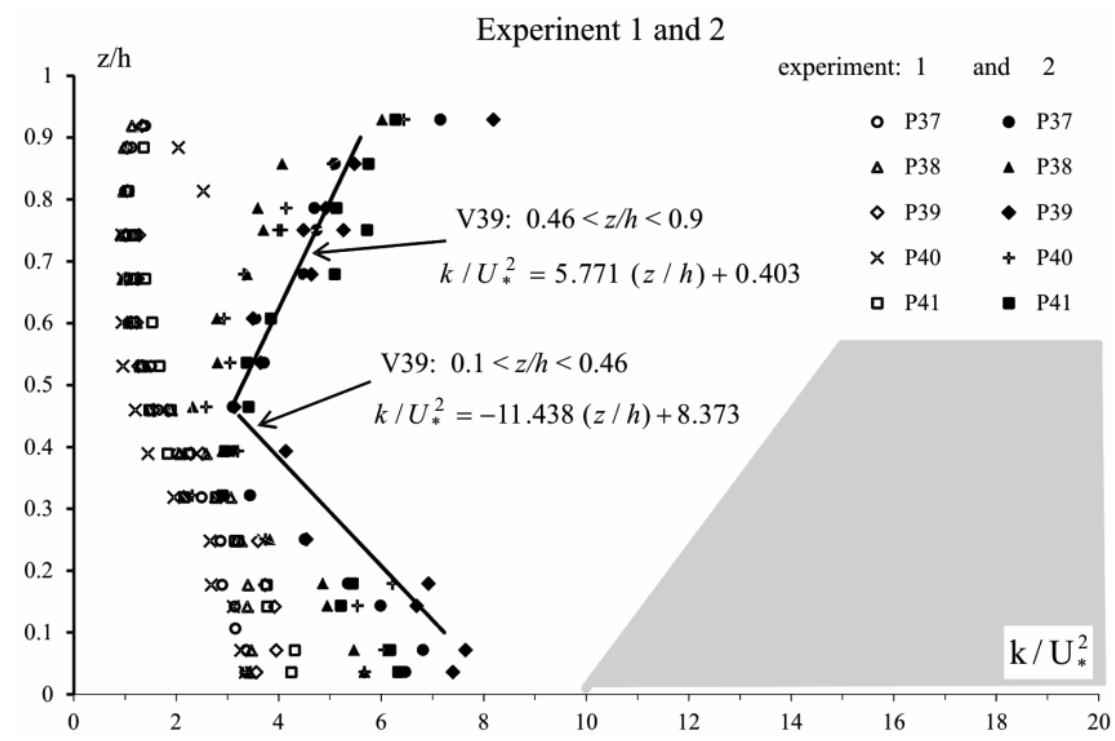

FIGURE 7. Vertical distributions of turbulent kinetic energy $k / U_{*}^{2}$ over the bed of the main channel in experiment 1 and 2

$$
k / U_{*}^{2}=5.771(z / h)+0.403
$$

Comparing both experiments (Fig. 7) a considerable influence of trees, located on floodplains, on vertical distributions of TKE is visible. The trees caused the increase of TKE values, the highest in region near the bed and at water level. The increase of turbulent kinetic energy in the zone close to the water surface is caused by energy production in the process of strong mixing of water and mass exchange between the main channel and vegetated floodplains. Also in this zone a considerable increase of longitudinal turbulence intensity take place, which can be related with the increase of absolute Reynolds stresses. However, the increase of kinetic energy at the bottom results from bed shear stresses (Grinvald and Nikora 1988).

Trees on the floodplains have caused the increase of TKE in the main cha- nnel and the decrease on floodplains (Fig. 4). In both experiments, the highest TKE values occur in the zone, where the main channel area joins and the floodplain area. In the vertical that joins both areas (vertical 30) trees have caused the change of TKE trend, from decreasing to increasing upwards to the water surface.

In the verticals of single channels, 3 zones of flow field can be determined: near the bed regions - ,wall region”, the intermediate and at water level regions - "free-surface region" (Nezu and Nakagawa 1993). The analyzed distributions prove, however, that in compound channels such zones can be distinguished on floodplains and over the banks of the main channel, almost for the whole channel width. Four zones can be determined over the bottom of the main channel. The zone near the channel bed to the depth of $0.1 \mathrm{z} / \mathrm{h}$, the zone close to the water surface, higher than $0.9 \mathrm{z} / \mathrm{h}$ and the middle 
zone, which clearly consists of two parts. The lower middle zone, which is located below floodplains elevation, is called the inner (inbank), middle zone, and the upper middle zone is considered to be outer (outbank), middle zone. The inner zone is mainly influenced by the bottom and the banks of the main channel, while the outer zone is influence by the interaction between the main channel and the floodplains. A considerable growth of interaction, caused by the vegetation on floodplains, have decreased the boundary between the main channel and floodplains from the floodplain elevation $0.56 \mathrm{z} / \mathrm{h}$ (Fig. 5) to about $0.46 z / h$ (Fig. 7).

\section{CONCLUSION}

The description of water turbulence in compound channels is complicated, insufficient and still requires the explanation of many scientific problems, despite a considerable interest in this field of research. Contemporary 3D measurements enable a significant refinement of turbulence structure description. The consideration of the interaction between the main channel and floodplains in the case of compound channels and also the consideration of the influence of tall floodplain vegetation, require repeated recognition of turbulence characteristics and more complete turbulence structure description. These issues justified the scope of the performed research. Presented results are based on instantaneous, 3-dimensional velocity measurements in a compound channel with rough floodplains and rough channel banks and with smooth main channel bottom. The research was performed for two different conditions of water flow: with and without trees on floodplains.
In the channel without trees, TKE values increase downwards to the bottom on floodplains and over main channel banks, where in general the best fit of TKE distribution is reached by linear regression equations in the range: $0.1<z / h<$ $<0.81$. The vegetation, although it causes the increase of turbulence intensity in the near surface zone, and the decrease of turbulence intensity in the near-bottom zone and over the banks of the main channel, does not influence the increase of turbulent kinetic energy on floodplains, but decreases it considerably. The vegetation also contributes to more uniform vertical turbulent kinetic energy distribution both on the floodplains and over the main channel banks.

Over the bottom of the main channel, from the floodplain elevation, TKE values increase downwards to the bottom, and the best fit for the description of that increase is the linear regression equation (Eq. 3 ) in the range $0.1<z / h<0.56$. Over the floodplain elevation, TKE values are constant with depth in the range: $0.56<z / h<0.9$. Floodplain vegetation caused a considerable increase of TKE both at the bottom and at the surface and the decrease of the elevation at which TKE trend changes: from the floodplain elevation $(0.56 \mathrm{z} / \mathrm{h}$, Fig. 5) to about $0.46 z / h$ (Fig. 7). Below that elevation, TKE values increase more rapidly downwards to the bottom and the relevant distribution of TKE was described by linear regression equation (Eq. 4) in the range $0.1<z / h<0.46$. For depths higher than $z / h=0.46$, the increase of TKE was observed, which was described by the linear regression equation (Eq. 5) in the range of $0.46<z / h<0.9$.

The areas of the presence of increased turbulent kinetic energy are the channel 
banks, the zone of channel and floodplain interaction, and also the floodplains without trees. The transverse turbulence intensity reaches high values in compound channels, especially in the interaction zones and on the floodplains, and they exert a high influence on the values of turbulent kinetic energy.

The performed research proved the vertical distribution of turbulent kinetic energy and the division into 3 zones of flow field on floodplains and over channel banks, and four zones over the bottom of the main channel: near the bed regions, the intermediate regions inner and outer, and at water level regions.

\section{Acknowledgements}

This study was supported by the Polish Ministry of Education and Science - grant no 2 P06S 02829.

\section{REFERENCES}

BABAEYAN-KOOPAEI K.; ERVINE D.A., CARLING P.A., CAO Z. 2002: Velocity and Turbulence Measurements for Two Overbank Flow Events in River Severn. J. Hydraul Eng., 128(10), 891-900.

BEN MEFTAH M., DE SERIO F., MALCANGIO D., PETRILLO A.F. 2006: Experimental study of flexible and rigid vegetation in an open channel. River Flow 2006. Proceedings of the International Conference on Fluvial Hydraulics, Lisbon, Portugal.

CZERNUSZENKO W., KOZIOŁ A., ROWIŃSKI P.M. 2007: Measurements of 3D Turbulence Structure in a Compound Channel. Archives of Hydro-Engineering and Environmental Mechanics, Institute of Hydro-Engineering PAS, ISSN 1231-3726, 54(1), Gdańsk, Poland, 3-21.

CZERNUSZENKO W., LEBIECKI P. 1980: Turbulent characteristics of stream in open channel. Archiwum Hydrotechniki, Vol. 27, 1, 19-38.

GRINVALD D.I., NIKORA V.I. 1988: The turbulence of rivers (in Russian). Hydrometeoizdat, Leningrad, Rosja.
INGO S., ORAL Y., SEDAT K. 2007: The effect of permeability of natural emergent vegetation on flow velocities and turbulence. $32^{\text {nd }}$ Congress of IAHR, the International Association of Hydraulic Engineering and Research, July 1-6, 9 pages. Venice, Italy.

KNIGHT X., SHIONO X. 1990: Turbulence measurements in a shear layer region of a compound channel. J. Hydraul. Res., 28(2), 175-196.

KOZIOŁ A. 2002: Mikrowiry Kołmogorowa w korycie o złożonym przekroju poprzecznym [The Kolmogorov microscale in the compound channel]. Wiadomości Instytutu Meteorologii $i$ Gospodarki Wodnej, Tom XXV (XLVI), 1, 37-42 [Engl. summ.].

KOZIOŁ A. 2008: Badanie czasowej i przestrzennej makroskali turbulencji w korycie o złożonym przekroju poprzecznym [Investigation of the time and spatial macro-scale of turbulence in a compound channel]. Acta Scientiarum Polonorum - Architectura 7(4), 15-23 [Engl. Summ.].

KOZIOŁ A., KUBRAK J., KUŚMIERCZUK K. 1998: Charakterystyki turbulencji strumienia w korycie o złożonym przekroju poprzecznym [Turbulence characteristics of a stream in a compound channel]. Zeszyty Problemowe Postępów Nauk Rolniczych Polskiej Akademii Nauk, Wydziat Nauk Rolniczych i Leśnych, 458, 75-87 [Engl. summ.].

MAZURCZYK A. 2007: Pola prędkości turbulentnych w kanałach o złożonych przekrojach poprzecznych $\mathrm{z}$ drzewami [Turbulent velocity fields in channels with compound cross-sections with trees]. PhD Thesis, Institute of Geophysics, Polish Academy of Sciences [Engl. abs.].

MAZURCZYK A. 2007: Scales of Turbulence in Compound Channels with Trees on Floodplains. Publs. Inst. Geophys. Pol. Acad. Sc., E-6 (390).

NEPF H.M. 1999: Drag, turbulence, and diffusion in flow through emergent vegetation. Water Resour. Res., 35(2), 479-489.

NEPF H.M., VIVONI E.R. 1999: Turbulence structure in depth-limited, vegetated flow: Transition between emergent and submerged regimes. Proc. 28. IAHR Congress, Graz, Austria, D1.

NEZU I., NAKAGAWA H. 1993: Turbulence in Open-channel Flows. IAHR Monograph, Balkema, Rotterdam. 
NEZU I., RODI W. 1986: Open-channel flow measurements with a Laser Doppler Anemometer. Journal of Hydraulic Engineering, 112(5), 335-355.

NIKORA V.I., ROWIŃSKI P., SUKHODOLOV A., KRASUSKI D. 1994: Structure of river turbulence behind warm-water discharge. Journal of Hydraulic Engineering, 120(2), 191-208.

NIKORA V.I., SMART G.M. 1997: Turbulence Characteristics of New Zealand Gravel-Bed Rivers. Journal of Hydraulic Engineering, 123(9), 764-773.

ROWIŃSKI P.M., ABERLE J., MAZURCZYK A. 2005: Shear velocity estimation in hydraulic research. Acta Geophysica Polonica, 4, 567-583.

ROWIŃSKI P., CZERNUSZENKO W., KOZIOŁ A., KUŚMIERCZUK K., KUBRAK J. 1998: Longitudial turbulence characteristics in a compound channel under various roughness conditions. Proceedings of the 3rd international conference on Hydro-Science and -Engineering, Cottbus/Berlin, Germany.

ROWIŃSKI P. M., CZERNUSZENKO W., KOZIOŁ A.P., KUBRAK J. 2002: Properties of Streamwise Turbulent Flow Filed in an Open Two-Stage Channel. Archives of Hydroengineering and Environmental Mechanics, 49(2), 37-57.

ROWIŃSKI P.M., MAZURCZYK A. 2006: Turbulent characteristics of flows through emergent vegetation. Proceedings of River Flow 2006, Lisbon, Portugal, 623-630.

SANJOU M., NEZU I., SUZUKI S., ITAI I. 2010 Turbulence structure of compound open-channel flows with one-line emergent vegetation. Proceedings of 9th International Conference on Hydrodynamics, Shanghai, China. 560-564.

SCHNAUDER I. 2004: Interaction processes in straight compound channel with rigid and flexible emergent floodplain vegetation. River Flow 2004, Taylor \& Francis Group, London. 347-352.

TERRIER B., ROBINSON S., SHIONO K., PAQUIER A., ISHIGAKI T. 2010: Influence of vegetation to boundary shear stress in open channel for overbank flow. River Flow 2010 - Dittrich, Koll, Aberle \& Geisenhainer (eds). Bundesanstalt für Wasserbau. 8 pages.
YANG K., CAO S. KNIGHT D.W. 2007: Flow Patterns in Compound Channels with Vegetated Floodplains. Journal of Hydraulic Engineering, 133(2), 148-159.

Streszczenie: Turbulentna energia kinetyczna strumienia wody $w$ korycie o złożonym przekroju poprzecznym. Celem badań eksperymentalnych było wyznaczenie zmian turbulentnej energii kinetycznej strumienia wody w korycie o złożonym przekroju poprzecznym, bez sztywnej i ze sztywną niezanurzoną roślinnością znajdującą się na terenach zalewowych. Wykonano dwa doświadczenia dla dwóch różnych wariantów chropowatości powierzchni terenów zalewowych. W pierwszym doświadczeniu powierzchnia dna koryta głównego była gładka, a skarpy koryta głównego i tereny zalewowe pokryte były lastryko na zaprawie cementowej. W drugim doświadczeniu dodatkowo na terenach zalewowych rozmieszczono roślinność wysoką (drzewa), którą zmodelowano aluminiowymi rurkami. Pomiar trzech składowych chwilowych prędkości wykonywano sondą akustyczno-dopplerowską ADV. Przedstawiono wpływ drzew z terenów zalewowych na rozkłady turbulentnej energii kinetycznej w korycie głównym i na terenach zalewowych. Rozkłady turbulentnej energii kinetycznej w funkcji głębokości opisano równaniami regresji. Rozkłady turbulentnej energii kinetycznej w pionie na terenach zalewowych i nad skarpami koryta głównego podzielono na trzy strefy, natomiast nad dnem koryta głównego wydzielono cztery strefy, przy czym w strefie środkowej pola przepływu są dwie strefy o różnych trendach.

Słowa kluczowe: koryto o złożonym przekroju poprzecznym, turbulentna energia kinetyczna, roślinność, tereny zalewowe.

\section{MS. received October 2011}

\author{
Author's address: \\ Adam P. Kozioł \\ Katedra Inżynierii Wodnej \\ Szkoła Główna Gospodarstwa Wiejskiego \\ ul. Nowoursynowska 166 \\ 02-787 Warszawa \\ Poland \\ e-mail: adam_koziol@sggw.pl
}

